\title{
Investigation of the Textbooks Based on Problem Based Learning to Improve Student Learning Outcomes in Thematic Learning
}

\author{
Maulana Agung Prabowo ${ }^{1}$, Sarwanto ${ }^{2}$, Roemintoyo ${ }^{3}$
}

\section{ARTICLE INFO}

\section{Article History:}

Received 11.10.2019

Received in revised form

25.06.2020

Accepted

Available online 01.10.2020

\begin{abstract}
The purpose of this study is to develop textbooks based on problem based learning to improve learning outcomes of fourth grade elementary school students. This article is a research and development that follows the Sukmadinata research procedure. This research consists of three stages, namely the exploration phase, the development stage and the testing stage. The output of this research is problem based learning textbooks that are effective for implementation in the classroom. The application in the class shows that textbooks based on problem based learning can improve student learning outcomes in thematic learning on the theme of Beautiful Diversity in My Country. This improvement can also contribute to the success of teachers towards the implementation of the 2013 curriculum. In addition, this Problem Based Learning (PBL) approach can motivate students in the learning process while helping to understand students' concepts. Moreover, the theme we raised in research (The Beautiful Diversity in My Country) can improve students' critical thinking skills in exploring things in their own country.
\end{abstract}

(C) IJERE. All rights reserved

Keywords:

Learning outcome, problem based learning, text book, thematic learning

\section{INTRODUCTION}

Education is a process in order to influence students so they can adjust to their environment thereby causing changes in themselves that enable it to function in people's lives. Teaching is in charge of directing this process so that the goals of the change can be achieved as desired (Rijal, 2016). Meanwhile, changes in the education curriculum are the impact of the rapid flow of globalization. The development of the National curriculum becomes important in line with the advancement of science, technology, and cultural arts as well as changes in society at the local, national, regional and global levels in the future. The theme of the 2013 curriculum is to produce Indonesian people who are productive, creative, innovative, affective through strengthening integrated attitudes, skills and reinforcement (Sumiyati, 2013). Therefore, to realize this in the implementation of the curriculum, teachers are required to professionally design effective and meaningful learning, organize learning, and choose the right learning approach.

On the other hand, one of the challenges in implementing the 2013 curriculum is the textbook. A textbook is a set of learning tools or tools that contain learning material, methods, boundaries, and ways of evaluating systematically and attractively designed in order to achieve the expected goals, namely achieving competence or basic competence with all its complexity (Lestari, 2012). According to National Center for Competency Based Training (Prastowo, 2015, p. 16) teaching materials are all forms of materials used to help the teacher or instructor in carrying out the learning process in class, the material in question can be either written material or unwritten material. Textbooks are needed as learning resources. Textbooks create an environment or atmosphere that allows students to learn. Textbooks in the 2013 curriculum have been designed systematically, interestingly, and adjusted to the conditions of students, but the 2013 curriculum focuses on simplifying curriculum content and applying integrative thematic learning (especially at elementary school level). This of course will have an impact on the provision of new textbooks. Moreover, the facts found in the field, namely the student books that have been provided by the government, mostly only contain student worksheets, while the learning materials used as sources of information are still lacking. The teacher also still has difficulty in explaining the material thematically, especially for the upper class, namely class IV to class VI. Learning material in the 2013 curriculum is simpler than the 2006 curriculum, because in the 2013 curriculum the material is integrated on one theme to discuss all teaching materials so that teachers will need more time to find learning resources and reference textbooks for teaching. In fact, the learning process requires a learning model that can improve learning outcomes.

${ }^{1}$ Corresponding Author, s2pgsdmaulana @student.uns.ac.id, Universitas Sebelas Maret, Indonesia, orcid.org/ 0000-0002-1876-6456

${ }^{2}$ Universitas Sebelas Maret, Indonesia, orcid.org/ 0000-0002-9602-5776

${ }^{3}$ Universitas Sebelas Maret, Indonesia, orcid.org/ 0000-0003-1152-1226 
Based on the description above, researchers try to develop textbooks that are inserted innovative learning models. One learning model that is developed and refers to an active and enjoyable learning process is the Problem Based Learning (PBL) learning model. Unlike other models whose emphasis is on presenting ideas and demonstrating skills, in Problem Based Learning (PBL), the teacher offers problem situations to students and instructs them to investigate and find their own solutions (Arends, 2008, p. 41). The same thing was expressed by Ceker and Ozdamil that Problem Based Learning (PBL) is a learning method through which students acquire and develop top-level skills such as problem solving and critical thinking while obtaining information from personal real-life experiences and gaining decisive knowledge about their learning alone. This model utilizes a constructivist approach, in which students try to solve everyday problems in a collaborative environment (Ceker \& Ozdamli, 2016). This opinion is strengthened by the results of research Safitri, et al who found that the problem based learning model of learning affects student learning independence and student communication skills in learning (Safitri, Sari, \& Dewi, 2019).

With the development of textbooks based on problem based learning, the learning process can be controlled by the intelligence of individuals who are in a group to solve meaningful, relevant, and contextual problems. This is because PBL is based on constructivist theory which is a learning approach that uses real world problems as a context for students to learn about critical thinking and problem solving skills as well as to gain knowledge and concepts that are essential from the subject matter (Yasa \& Bhoke, 2018). With the problem based learning textbooks, the researchers hope the thematic learning that is the hallmark and objectives of the 2013 curriculum can be achieved. As expressed by the Ministry of Education and Culture, thematic learning integrates various competencies from various subjects into various themes. The integration is carried out in two ways, namely the integration of attitudes, skills, and knowledge in the learning process and the integration of various related basic concepts. The theme knits the meanings of various basic concepts so that students do not learn basic basic concepts partially (Ministry of Education and Culture, 2013). The general purpose of this research and development is to produce problem based learning textbooks for grade IV elementary school students in Surakarta City, Province of Central Java, Indonesia. The specific objectives of this research and development are to (1) describe the process and results of developing valid and practical problem based learning textbooks in improving the learning outcomes of grade IV elementary school students and (2) describing the conditions of learning using text based problem based learning textbooks in class IV Surakarta City, Province of Central Java, Indonesia.

\section{METHOD}

This type of research is research and development. Researchers use the $\mathrm{R} \& \mathrm{D}$ research model because it seeks to develop a product in the form of integrative thematic teaching materials with the PBL approach to learning. This developmental research is focused on developing integrative thematic teaching material products in grade IV elementary school. Research and development is a process or steps to develop a new product or improve existing products that can be accounted for (Sukmadinata, 2016, p. 164). Research and development methods or in English Research and Development is a research method used to produce certain products, and test the effectiveness of these products (Sugiyono, 2015, p. 297). The procedure of research and development of thematic learning textbooks with the PBL approach in grade IV elementary school students according to the research model according to Sukmadinata (2016:172-182) which includes: (1) the exploration phase (preliminary study), (2) the development stage, and (3) the testing phase. The number of samples in this study were sixty students who were grouped into two groups. The first group became the control group, while the second became the experimental group. Both groups have used the same curriculum, the 2013 curriculum.

\section{RESULT}

Thematic learning textbooks with the PBL approach have undergone various revisions from the initial preparation and validated by designated experts, then limited trials and extensive trials are carried out and further improvements are tested for effectiveness through quasi experimental. Quasi-experiments are carried out if the researcher cannot control fully through the use of randomization procedures, so it must use a design that can provide as much control as possible in the situation. This is in accordance with what is 
experienced by researchers in order to test the effectiveness of instructional materials, where researchers do not allow full control of the existing variables (Arif, 2011, p. 394).

This effectiveness test is carried out to see how much the influence of thematic learning teaching materials with the PBL approach when applied will have an impact on students in changing abilities and attitudes in learning. Thematic learning material products with the PBL approach that have been made and then carried out treatment or treatment through experimental and control classes. The implementation of learning is designed in accordance with the learning tools that have been prepared namely using thematic learning teaching materials with the PBL approach. This is intended to determine the achievement of student learning outcomes and evaluate more deeply the products that have been developed previously at the trial stage. Testing the results of treatment is carried out using one group pretest-posttest design (Sugiyono, 2015, p. 303).

Before testing the hypothesis, first a balance test is carried out, namely the normality test, the homogeneity test, and the initial ability test.

\section{a. Pretest Normality Test}

Normality test is used to determine whether the sample taken is from a normal distribution population or not. This normality test uses the Kolmogorov-Smirnov formula. The results of the calculation of the normality test of the experimental class and the control class with a significance level of 0.05 are presented in Table 1 below.

Table 1. Pretest Normality Test

\begin{tabular}{|c|c|c|c|c|}
\hline Group test & Mean & SD & Significance Value & Decision \\
\hline Control & 60,53 & 15,75 & 0,660 & Normal distribution \\
\hline Experiment & 58,00 & 14,10 & 0,864 & Normal distribution \\
\hline
\end{tabular}

Based on the data shown in table 1 of the normality test results, it is known that the normality test results with a significance value is greater than the probability of 0.05 . Thus the data is normally distributed.

\section{b. Pretest Homogeneity Test}

Homogeneity test uses SPSS 21 with the Levene-statistical formula with a significance level of 0.05 . The following is the homogeneity test results in the control class and experimental class.

Table 2. Pretest Homogeneity Test

\begin{tabular}{ccc}
\hline Group test & Significance Value & Decision \\
\hline $\begin{array}{c}\text { Control } \\
\text { Experiment }\end{array}$ & 0,461 & Homogen \\
\hline
\end{tabular}

Based on the data shown in homogeneity test results, it is known that the homogeneity test results with a significance value is greater than the probability of 0.05 . Thus the data can be said to be homogeneous.

\section{c. Initial Ability Test}

Following are the results of the initial capability analysis.

Table 3. Preliminary Ability Test Results

\begin{tabular}{ccccl}
\hline Group test & Average Value & $\mathrm{N}$ & Significance Value & Decision \\
\cline { 1 - 5 } Control & 60,53 & 30 & 0,655 & $\begin{array}{l}\text { There is no } \\
\text { significant } \\
\text { difference }\end{array}$ \\
\hline Experiment & 58,00 & 30 & &
\end{tabular}

Based on the results table of the initial ability analysis using SPSS, it can be concluded that the initial abilities of the control class and the experimental class are the same.

After tests of normality, homogeneity, and initial ability. The next step is to test the hypothesis. The following is the presentation of posttest data results. 


\section{d. Posttest Normality Test}

The results of the calculation of the normality test of the experimental class and the control class with a significance level of 0.05 are presented in table 4 below.

Table 4. Posttest Normality Test

\begin{tabular}{ccccc}
\hline Group test & Mean & SD & Significance Value & Decision \\
\hline Control & 68,80 & 13,05 & 0,865 & Normal distribution \\
\hline Experiment & 85,07 & 11,26 & 0,682 & Normal distribution \\
\hline
\end{tabular}

Based on the data shown in table 4 the normality test results, it is known that the normality test results with a significance value is greater than the probability of 0.05 . Thus the data is normally distributed.

\section{e. Posttest Homogeneity Test}

Homogeneity test uses SPSS 21 with the Levene-statistical formula with a significance level of 0.05 . The following is the homogeneity test results in the control class and experimental class.

Table 5. Posttest Homogeneity Test

\begin{tabular}{ccc}
\hline Group test & Significance Value & Decision \\
\hline Control & 0,390 & Homogen \\
\cline { 1 - 1 } Experiment & &
\end{tabular}

Based on the data shown in table 5 homogeneity test results, it is known that the homogeneity test results with a significance value is greater than the probability of 0.05 . Thus the data can be said to be homogeneous.

\section{f. Final Ability Test Results}

The final ability test was conducted to answer the questions in this study, is whether problem based learning textbooks are effective for improving student learning outcomes. The results of the balance test concluded that the two samples came from populations that were normally distributed and homogeneous. The implementation of learning in the experimental class is the same as learning in the pilot class, namely learning using textbooks with a problem based learning approach. Meanwhile learning in the control class uses textbooks that are usually used by teachers. Data analysis was performed based on students' learning achievement test data. The following are the results of the $t$ test analysis with the help of SPSS.

Table 6. Final Ability Test Results

\begin{tabular}{ccccc}
\hline Group test & Average Value & $\mathrm{N}$ & Significance Value & Decision \\
\hline Control & 68,80 & 30 & 0,00 & $\begin{array}{c}\text { There are } \\
\text { significant } \\
\text { Experiment }\end{array}$ \\
\hline
\end{tabular}

Based on the results of the final ability analysis using SPSS, it can be concluded that there are significant differences in the learning outcomes of the control class and the experimental class. The table above shows that the average learning outcomes of the experimental class are higher than the average learning outcomes of the control class. This shows that the thematic textbooks with effective problem based learning approaches to improve student learning outcomes.

\section{g. Gain Score Test}

Individual gain test results indicate that there are students who get the category of moderate normalized gain scores and low normalized scores. Calculation of overall gain score as follows:

gain score $=(85,06667-58,8) /(100-58,8)=0,637$

Based on these results the gain score $>0.30$ can be said that the normalized gain score is moderate.

\section{DISCUSSION}

Books as teaching materials are books that contain a knowledge of the results of analysis of the curriculum in written form (Majid, 2014, p. 176). This explanation implies that the book contained knowledge that was compiled based on the curriculum. The preparation of textbooks also has two main 
missions, namely the optimization of the development of declarative knowledge and procedural knowledge, and that knowledge must be the main target of textbooks used in schools (Prastowo, 2015, p. 245).

On the other hand, the application of the 2013 curriculum for elementary school level from class I to class VI is learning that is packaged in the form of themes (thematic). The theme is a container or vehicle to introduce various material concepts to students as a whole. Thematics are provided with the intention of uniting curriculum content in whole units or units and making learning more integrated, meaningful, and easily understood by elementary / MI students. As Forgarty said that applying integrative thematic learning not only integrates a variety of subjects, but can also integrate the students' skills, attitudes and knowledge (Abidin, 2014, p. 210).

In summary, problem based learning activities begin with the activities of students to solve real problems that are determined or agreed upon. The problem solving process has implications for the formation of students' skills in solving problems or critical thinking as well as forming new knowledge. Trianto argues that the problem based learning model is a learning model that is based on the many problems that require authentic inquiry that is investigations that require real resolution of real problems (Trianto, 2010, p. 90).

The problem based learning textbooks that we have developed have proven to be effective in improving student learning outcomes in thematic learning. This is because the problem based learning approach in the textbook is relistic to students 'lives, concepts according to students' needs, fostering student inquiry, conceptual memory becomes strong, and fostering problem solving abilities (Trianto, 2010, p. 91). This is also corroborated by the results of Murniyati and Winarto's research which found that in problem based learning there are good techniques to better understand the content of the lesson, challenge students 'abilities and give satisfaction to discover new knowledge, enhance learning activities, enhance students' ability to think critically and develop the ability of students to adapt to new knowledge, as well as provide opportunities for students to apply their knowledge to adjust to everyday life (Murniyati \& Wnarto, 2018, p. $31)$.

In addition to being seen from the results of student learning, teachers who use this textbook acknowledge that there is ease in conveying material to students. This is because the textbooks developed cover all aspects of the assessment of the quality of teaching materials put forward by the Ministry of National Education. There are four criteria for the evaluation of teaching materials, namely aspects of content worthiness, aspects of language, aspects of presentation, and aspects of graphics (Ministry of Education, 2008, p. 28). Achievement of textbooks based on effective problem based learning to improve student learning outcomes is also inseparable from the suggestions and criticisms from various parties (teachers, principals, and experts) who always assist researchers in improving this textbook. What's more, the problem based learning model is proven to be able to improve learning outcomes in several subjects, such as natural science (Rahmasari, 2016) and mathematics (Yasa \& Bhoke, 2018).

Problem based learning is a teaching method that aims to prepare students for real-world settings. By requiring students to solve problems as the main format of teaching, PBL improves student learning outcomes by promoting their abilities and skills in applying knowledge, solving problems, practicing higherlevel thinking, and directing themselves and reflecting their own learning (Ceker \& Ozdamli, 2016, p. 196). In line with this, Birmingham, et al argue that students can utilize (1) integrate existing cultural practices / expertise into science learning and implementation and (2) incorporate learning outcomes that go beyond content acquisition, they participate in scientific inquiry, build tools that strong to represent scientific thought (Birmingham, Coleman, \& Smetana, 2019, p. 1497).

Learning is a form of change experienced by students in terms of their abilities aimed at changing behavior by means of the interaction between stimulus and response (Nahar, 2016). Piaget is of the opinion that children interact with their surroundings in overcoming the problems they face in their environment. Learning occurs in problem solving activities (Saomah, 2017, p. 6). Whereas thematic learning integrates various competencies from various subjects into various themes (Ministry of Education and Culture, 2013, p. 9). This is in accordance with the characteristics of the problem based learning model which, according to Davidsen, et al, this model is highlighted as a pedagogical model that supports students in obtaining transversal competencies such as collaboration, communication, critical thinking and problem solving skills (Davidsen, Andersen, \& Christiansen, 2019). 
The benefits of applying the problem based learning model in class for teachers and students are (1) PBL allows students to take on their own learning responsibilities; (2) group projects allow students to develop their adequacy in teamwork, and (3) individual homework allows advanced students to display their highest performance, leadership efforts, and creativity (Ceker \& Ozdamli, 2016). Thus, the learning model is a conceptual framework that describes systematic procedures governing learning experiences to achieve certain goals and serves as a guide for learning designers and teachers in designing and implementing learning (Ratoyo, Winarno, \& Slamet, 2019). The effectiveness of problem based learning textbooks in this study only applies to fourth grade students of elementary schools. Nevertheless, the problem based learning (PBL) model can be applied when the teacher wants students not only to remember the subject matter, but to master and understand fully and be able to solve problems. Learning in the classroom by developing problem based learning (PBL) is expected to foster a learning experience that is more challenging and enjoyable for students. That way this learning can improve student learning outcomes. But unfortunately, this research only focuses on theme of Beautiful Diversity in My Country (especially in Indonesia) and in-depth studies are still needed on the success of the education curriculum.

\section{REFERENCES}

Abidin, Y. (2014). Desain Sistem Pembelajaran dalam Konteks Kurikulum 2013. Bandung: Refika Aditama.

Arends, R. I. (2008). Learning to Teach. Yogyakarta: Pustaka Pelajar.

Arif, F. (2011). Pengantar Penelitian dalam Pendidikan. Yogyakarta: Pengantar Penelitian dalam Pendidikan.

Birmingham, D., Coleman, E., \& Smetana, L. (2019). From the beginning , i felt empowered: Incorporating an Ecological Approach to Learning in Elementary Science Teacher Education. Research in Science Education, 49, 1493-1521. https://doi.org/10.1007/s11165-017-9664-9

Ceker, E., \& Ozdamli, F. (2016). Features and characteristics of problem based learning. Cypriot Journal of Educational Sciences, 11(4), 195-202.

Davidsen, J., Andersen, P. V. K., \& Christiansen, E. (2019). Problem-based learning in a box: Lessons learned from an Educational design experiment. Journal of Problem Based Learning in Higher Education, 7(1), 120132.

Lestari, N. N. S. (2012). Pengaruh Model Pembelajaran Berbasis Masalah (Problem Based Learning) dan Motivasi Belajar terhadap Prestasi Belajar Fisika bagi siswa Kelas VII SMP. Program Studi Teknologi Pembelajaran Program Pasca Sarjana Universitas Pendidikan Ganesha Singaraja, Singaraja.

Majid, A. (2014). Pembelajaran Tematik Terpadu. Bandung: Remaja Rosdakarya.

Ministry of Education. (2008). Pengembangan Bahan Ajar dan Media. Jakarta: Ministry of Education.

Ministry of Education and Culture (2013). Modul Pelatihan Implementasi Kurikulum 2013. Jakarta.

Murniyati, \& Wnarto. (2018). Perbedaan Penerapan Model Project Based Learning (PjBL) dan Problem Based Learning (PBL) Ditinjau dari Pencapaian Keterampilan Proses Siswa. Pancasakti Science Education Journal, 3(1), 25-33.

Nahar, N. I. (2016). Penerapan Teori Belajar Behavioristik dalam Proses Pembelajaran. NUSANTARA: Jurnal Ilmu Pengetahuan Sosial, 1(1).

Prastowo, A. (2015). Pengembangan Bahan Ajar Tematik. Jakarta: Prenadamedia.

Rahmasari, R. (2016). Penerapan Model Pembelajaran Problem Based Learning untuk Meningkatkan Hasil Belajar IPA Kelas IV SD. Jurnal Pendidikan Guru Sekolah Dasar, 36(5).

Ratoyo, K. G., Winarno, \& Slamet, S. Y. (2019). Video media-based learning to improve the story writing ability of the 4th graders of public elementary schools in Cilacap Regency. International Journal of Educational Research Review, 4, 781-788. https://doi.org/10.24331/ijere.634886

Rijal, S. (2016). Efektivitas Pembelajaran Matematika Siswa melalui Penerapan Teori Belajar Bruner. In Prosiding Seminar Nasional (Vol. 02, pp. 489-495).

Safitri, E. M., Sari, Y., \& Dewi, R. F. K. (2019). Pengaruh Model Pembelajaran Problem Based Learning terhadap Sikap Mandiri dan Kemampuan Komunikasi Matematika Siswa Kelas V SD Negeri Bakalrejo 1. SQUARE: Journal of Mathematics and Mathematics Education, 1(2), 83-89.

Saomah, A. (2017). Implikasi Teori Belajar terhadap Pendidikan Literasi. Medan: http://repository. usu. ac. id.

Sugiyono. (2015). Metode Penelitian Kuantitatif Kualitatif dan RED. Bandung: Alfabeta.

Sukmadinata, N. S. (2016). Metode Penelitian Pendidikan. Bandung: Remaja Rosdakarya.

Sumiyati. (2013). Implementasi Kurikulum 2013 Menuju Indonesia Maju. In Makalah Seminar Nasional 
Pendidikan Sains UNS.

Trianto. (2010). Mendesain Model Pembelajaran Inovatif-Progesif. Jakarta: Kencana Prenada Media Grup.

Yasa, P. A. E. M., \& Bhoke, W. (2018). Pengaruh Model Problem Based Learning terhadap Hasil Belajar Matematika pada Siswa SD. Journal of Education Technology, 2(2), 70-75. 